\title{
Microbiological and Biochemical Contamination Analysis of Refilled Drinking-water in Abeli, Kendari, Southeast Sulawesi
}

\author{
Juminten Saimin ${ }^{1, *}$, Hartati $^{2}$, Yenti Purnamasari ${ }^{2}$, Sufiah Asri Mulyawati² ${ }^{2}$ Tien $^{2}$, Pranita Aritrina ${ }^{2}$ \\ ${ }^{1}$ Departement Obstetrics and Gynecology, Faculty of Medicine, Universitas Halu Oleo, Kampus Bumi Tridharma Andonouhu, Kendari, Indonesia \\ ${ }^{2}$ Departement Biomedicine, Faculty of Medicine, Universitas Halu Oleo, Kampus Bumi Tridharma Andonouhu, Kendari, Indonesia \\ *Corresponding author. E-mail: inten_azis@yahoo.com
}

Received date: Jun 1, 2019; Revised date: Mar 18, 2020; Accepted date: Mar 20, 2020

\section{Abstract}

$\mathrm{B}$ ACKGROUND: The access to safe drinkingwater is increasingly difficult, especially in water catchment or coastal areas. Due to the difficulty, people in coastal areas tend to consume ready-to-use refilled drinking-water. However, the sanitation facilities on most drinking-water refill depots do not meet the requirements, hence really prone to microbial contamination. We conducted this study to determine the types of bacteria causing the contamination of refilled drinking-water from refill depots in Abeli, a coastal area in Kendari.

METHODS: Samples were collected from all 6 drinkingwater refill depots in Abeli. Three-series fermentation tubes were used for the microbiological test, including the presumptive, confirmative and completed tests. The biochemical test was performed with indole test, methyl red test, Voges-Proskauer test, and citrate utilization test (IMViC) methods and the triple sugar iron agar (TSIA) test.

RESULTS: Among 6 refilled drinking-water samples, we found the growth of coliform bacterial colonies in 3 samples, exhibiting various characteristics. Based on the characteristics, both microbiological and biochemical, the identified bacteria were Proteus sp., Escherichia coli and Klebsiella oxytoca.

CONCLUSION: Bacteria that contaminated refilled drinking-water in Abeli were Proteus sp., E. coli and K. oxytoca. Continuous supervision is required to ensure the quality of water from drinking-water refill depots.

KEYWORDS: bacteria, Proteus sp., Escherichia coli, Klebsiella oxytoca, coastal areas, refilled drinking water

Indones Biomed J. 2020; 12(2): 124-9

\section{Introduction}

Water is the most important element for human body, and adequate water intake is necessary. An individual needs at least $1.5 \mathrm{~mL}$ of water intake for each calorie they consumed. (1) Meanwhile during pregnancy, water requirements will also increase to support the fetal circulation, amniotic fluid production, and increased blood volume. Because of the increased energy requirements, pregnant women need at least $300 \mathrm{~mL}$ of additional water intake per day. $(1,2)$ Safe drinking-water can be described as water that is free of chemical substances and micro-organisms which cause abnormalities. It should not possess significant risk to health over a lifetime of consumption.(3) The access to safe drinking-water sources varies in several places, and some communities may find it hard to obtain safe drinkingwater. $(3,4)$ Access to safe drinking-water is increasingly difficult, especially in water catchment areas that have been converted into residential areas. Industrial waste and global warming also lead to healthy water crisis.(4-6)

Indonesia, as an archipelago, has many coastal areas those are potential for development. However, the increasing population growth and various rapid development activities in coastal areas cause the reduction of water catchment and the increment of ecological pressure on ecosystems. 
(5) According to Basic Health Research/Riset Kesehatan Dasar (RISKESDAS) in 2013, the sources of drinkingwater in Indonesia were from bottled water, refilled water (from drinking-water refill depots), tap water, bore wells or pumps, protected wells, springs, rain, and river water storage or irrigation.(7)

In Indonesia, the requirements about drinkingwater in are regulated in the Regulation of the Minister of Health No.492/Menkes/Per/IV/2010. They have to meet the physical, chemical, microbiological and radioactive requirements. Drinking-water should be clear, colorless, tasteless, odorless, and not corrosive. It also should not contain pathogenic bacteria, chemicals, or anything that might be harmful to health. $(8,9)$ Drinking-water providers are obliged to ensure that the drinking-water they produced is safe for public consumption. To ascertain it, the quality needs to be monitored. $(8,10)$

Due to the difficulties to obtain healthy water, people in the coastal areas tend to consume ready-to-use drinkingwater, hence the number of drinking-water refill depots are increasing lately. However, consuming refilled drinkingwater may have the risk of microbial contamination, including the Escherichia coli contamination, which potential to cause waterborne diseases. $(4,10)$ Previous study conducted in Kendari found that the refilled drinkingwater in the coastal areas was contaminated with coliform bacteria.(11) In other study, it was also found that the sanitation facilities on most drinking-water refill depots did not meet the requirements.(12)

E. coli are opportunistic bacteria that are found in the large intestine of humans as a normal flora. It can cause primary infections in the intestine, such as malabsorption, diarrhea and dysentery. Diarrhea is an endemic disease in Indonesia which often inducing an outbreaks that accompanied by death. According to the results of RISKESDAS 2013, the incidence of diarrhea based on symptoms and the prevalence of diarrhea in Southeast Sulawesi were $3.5 \%$ and $7.3 \%$, respectively.(7) Besides E. coli, there are other bacteria that caused many health problem, for example Klebsiella oxytoca and Proteus sp.

Since people in the coastal areas have high tendency to consume refilled drinking-water, therefore, it is necessary to conduct microbiological and biochemical examinations to determine the type of bacteria contaminating the refilled drinking-water. This study aimed to determine the types of bacteria causing the contamination of refilled drinkingwater from refill depots in Abeli, a coastal area in Kendari, Southeast Sulawesi.

\section{Methods}

Samples were collected directly from all 6 drinking-water refill depots in Abeli, district, one of the coastal area in Kendari, Southeast Sulawesi. The bacteria identification was carried out by the microbiological and biochemical tests at Microbiology Laboratory, Faculty of Medicine, Universitas Halu Oleo, Kendari, in June 2017. This study was approved by the Health Research Ethics Commission of Universitas Halu Oleo (No.841/UN29.20/PPM/2017).

\section{Microbiological Test}

For the bacteriological testing, 3-series fermentation tubes were used and the results of this test would be reported in most probable number (MPN) index. The MPN method is used to estimate the concentration of viable microorganisms in a sample, and consisted of 3 tests, which were presumptive, confirmative and completed tests.

The presumptive test was performed using the lactose broth (LB) medium to detect the fermentative coliform properties. LB contained peptone and meat extract which provided essential nutrients for bacterial metabolism and as a source of carbohydrates that could be fermented by coliform bacteria. One tube of $50 \mathrm{~mL}$ single strength and 5 tubes of $10 \mathrm{~mL}$ double strength for each water sample were inoculated and incubated at $37^{\circ} \mathrm{C}$ for 24 hours.(13) The turbidity and gas bubbles in the Durham's tube showed that the presumptive test was positive although still in low probability level.

Confirmative test was performed using the brilliant green lactose bile broth (BGLB) medium, a selective differential medium, to ensure the presence of coliform. Using a sterile one wire loop, the inocula from the positive LB tubes were transferred into a tube containing BGLB media and Durham's tubes, and then incubated at $37^{\circ} \mathrm{C}$ for 24 hours.(13)

Completed test was performed using eosin methylene blue (EMB) agar and gram-staining. The bacteria were inoculated on EMB agar, a differentiation medium for the isolation of coliform bacteria. Gram-staining was done to determine gram-positive and gram-negative bacteria. One loop of each positive culture was taken and inoculated on the EMB agar, and then incubated at $37^{\circ} \mathrm{C}$ for 24 hours. The growth of $E$. coli was characterized by the growth of greenish metallic colonies with diameter of 2-3 $\mathrm{mm}$.

To observe their shapes and colors, the colonies were gram-stained on the object glass. Crystal violet and iodine 
solution was added and soaked in safarin. The purple or blue spot was indicating gram-positive, while the red spot was indicating gram-negative.

\section{Biochemical Test}

The biochemical test was performed with IMViC methods and the triple sugar iron agar (TSIA) test. IMViC was a set of useful reactions that were commonly used in the identification of family enterobacteriaceae. The 4 reactions were consisted of indole test, methyl red (MR) test, VogesProskauer (VP) test, and citrate utilization test.

\section{IMViC Methods}

Indole reacted with the aldehyde in the reagent containing dimethyl-amino-benzaldehyde to produce a red color. The indole test was done by inoculating the colonies from the EMB agar on the sulphur, indole, motility (SIM) agar. The colonies were then incubated at $37^{\circ} \mathrm{C}$ for 24 hours and were given 1-3 drops of Kovac's reagent. Positive reactions were characterized by the presence of a red ring on the media layer, while a negative reaction was indicated by the formation of a yellow ring.(14)

The MR test detected the ability of bacteria to fermentation of glucose and produce acidic end products. $\mathrm{MR}$ was a $\mathrm{pH}$ indicator, which remained being red at $\mathrm{pH}$ of 4.4 or less. The colonies were inoculated into the tube containing $10 \mathrm{~mL}$ of MR-VP media and were incubated at $37^{\circ} \mathrm{C}$ for 24 hours. As much as 2-5 drops of the MR reagent were added into the tube. Positive results were indicated by a red colors, meanwhile the negative result was indicated by the yellow colors (no change in colors).(14)

The VP test detected the producer of butylene glycol. For the test, colonies were inoculated into the tube containing $10 \mathrm{~mL}$ of MR-VP media and were incubated at $37^{\circ} \mathrm{C}$ for 24 hours. Five millimeters of MR-VP medium was transferred into the test tube, then $0.6 \mathrm{~mL}$ of the alpha-naphthol and $0.2 \mathrm{~mL}$ of the $40 \%$ potassium hydroxide $(\mathrm{KOH})$ were added and shaken. The positive reaction was indicated by the eosin pink or red colors within two hours, and the negative reaction was indicated by the yellow colors (no change in colors).(14)

Citrate test was used to detect the ability of bacteria to utilize citrate as the main source of metabolism and growth. The citrate utilization test was done by inoculating the colonies into the citrate media (Simmon's citrate agar) and incubating it at $37^{\circ} \mathrm{C}$ for 24 hours. Positive result was indicated by changes in colors from green to blue, while the negative results were marked by the green colors.(14)

\section{TSIA Test}

TSIA test was used to see the ability of bacteria to ferment glucose, lactose and sucrose. The goal was to find out bacteria that produce gas and acids. For the TSIA test, the colonies were picked and cultured into the TSIA medium. TSIA was inoculated by stabbing through the center of the medium to the bottom of the tube and then streaking on the surface of the agar slant. It was covered and incubated overnight at $37^{\circ} \mathrm{C}$. Then the slant, butt, gas, and $\mathrm{H}_{2} \mathrm{~S}$ production were observed. The result considered as positive if there was a change in media colors from orange red to yellow on the slant and butt media. It was negative results if the media was red on the slant and butt media. The existence of gas was characterized by the rupture and lift of agar which was caused by the formation of $\mathrm{CO}_{2}$ gas. The $\mathrm{H}_{2} \mathrm{~S}$ formation was indicated by black deposits.(15)

\section{Results}

The presence of coliform bacteria can be an indicator of bad microbiological quality of clean water and drinking-water. Table 1 showed the microbiological examination result of refilled drinking-water in Abeli district, one of the coastal area in Kendari. Among 6 drinking-water refill depots we examined, three of it was not in accordance to the Regulation of Health Minister. We found a growth of coliform bacteria in the samples collected from those three drinking-water refill depots (samples no 1, 3, and 4).

To understand the morphological and biochemical characteristic of the contaminated refilled drinking water, we performed morphological tests, IMViC tests, and TSIA tests on the samples. The morphological characteristics of the three contaminated samples were rod-shaped, in red color, gram-negative, and non-spore-forming bacteria. The IMViC tests results were variative between the three contaminated samples. The indole test showed that all of the samples were positive, which was shown by the presence of a red ring on the media layer. While the MR, VP, and citrate tests exhibited various results. The TSIA test showed that there were red (positive) and yellow (negative) slant production, while all samples show yellow (negative) butt production. The gas production was all positive, while the $\mathrm{H} 2 \mathrm{~S}$ assessment was showing various results (Table 2).

Based on the Bergey's Manual of Systematic Bacteriology, the bacteria identified from sample no. 1 were screened as Proteus sp. (Figure 1). This was shown by the rod-shaped, gram-negative, and non-spore morphological characteristic, positive indole test, positve MR test, positive 
Table 1. Microbiological examination results of the refilled drinking-water samples.

\begin{tabular}{cccccc}
\hline \multirow{2}{*}{ Sample } & \multicolumn{2}{c}{ Three Serial Dilutions } & & \multicolumn{2}{c}{ Coliform (MPN/100 mL) } \\
\cline { 2 - 3 } \cline { 2 - 3 } & LB & BGLB & LB & BGLB \\
\hline 1 & $5 / 5,1 / 1,0 / 1$ & $5 / 5,1 / 1,0 / 1$ & & 96 & 96 \\
2 & $0 / 5,0 / 1,0 / 1$ & $0 / 5,0 / 1,0 / 1$ & & 0 & 0 \\
3 & $5 / 5,1 / 1,0 / 1$ & $5 / 5,0 / 1,0 / 1$ & & 96 & 38 \\
4 & $1 / 5,0 / 1,0 / 1$ & $1 / 5,0 / 1,0 / 1$ & & 22 & 22 \\
5 & $0 / 5,0 / 1,0 / 1$ & $0 / 5,0 / 1,0 / 1$ & & 0 & 0 \\
6 & $0 / 5,0 / 1,0 / 1$ & $0 / 5,0 / 1,0 / 1$ & 0 & 0 \\
\hline
\end{tabular}

Three serial dilutions (first using five tubes, second using one tube, third using one tube): $5 / 5=$ five out of five tube was positive; $1 / 5=$ one out of five tube was positive; $0 / 5=$ none of five tube was positive; $1 / 1=$ one out of one tube was positive; $0 / 1=$ none of one tube was positive. LB: lactose broth; BGLB: brilliant green lactose bile broth; MPN: most probable number.

citrate test, alkaline slant production, acid butt production, positive gas production, and positive $\mathrm{H}_{2} \mathrm{~S}$ production.

Meanwhile, the bacteria identified from sample no. 3 were screened as E. coli (Figure 2), which was characterized by the the rod-shaped, gram-negative, and non-spore morphological characteristic, positive indole test, positve MR test, acid slant production, acid butt production, and positive gas production.

The last contaminated sample, the bacteria identified from sample no. 4, showed the characterization of $K$. oxytoca (Figure 3). This was shown by the the rodshaped, gram-negative, and non-spore morphological characteristic, positive indole test, positive VP test, positive citrate test, acid slant production, acid butt production, and positive gas production.

\section{Discussion}

The presence of coliform bacteria in drinking-water generally suggests that the drinking-water may have been contaminated with either human's or animal's faeces. Coliform bacteria are enteropathogenic that interfere with human's health.(4) A growth of coliform bacteria colonies was found from the samples of this study. The Regulation of Health Minister determined that the maximum limit of coliform bacteria is 0 bacteria per $100 \mathrm{~mL}$ of water. Means that any presence of coliform bacteria in drinking-water indicates that the drinking-water is polluted.(9)

Completed test should be conducted to ensure the results of the confirmation test by detecting the nature of

Table 2. Morphological and biochemical characteristics of refilled drinking-water samples.

\begin{tabular}{|c|c|c|c|c|c|c|c|c|c|c|c|}
\hline \multirow{2}{*}{ Sample } & \multirow{2}{*}{ Colony on EMB Agar } & \multirow{2}{*}{ Morphology } & \multicolumn{4}{|c|}{ IMViC Methods } & \multicolumn{4}{|c|}{ TSIA Test } & \multirow{2}{*}{$\begin{array}{l}\text { Screened } \\
\text { Bacteria* }\end{array}$} \\
\hline & & & In & MR & VP & $\mathbf{C i}$ & Slant & Butt & Gas & $\mathrm{H}_{2} \mathrm{~S}$ & \\
\hline 1 & $\begin{array}{l}\text { Metallic colored colonies, } \\
\text { mucoid pink colonies }\end{array}$ & Rod-shaped, red color & + & + & - & + & K & A & + & + & Proteus sp. \\
\hline 2 & Negative & - & - & - & - & - & - & - & - & - & - \\
\hline 3 & $\begin{array}{l}\text { Metallic colored colonies, } \\
\text { mucoid pink colonies }\end{array}$ & Rod-shaped, red color & + & + & - & - & A & A & + & - & Escherichia coli \\
\hline 4 & Mucoid pink colonies & Rod-shaped, red color & + & - & + & + & A & A & + & - & Klebsiella oxytoca \\
\hline 5 & Negative & - & - & - & - & - & - & - & - & - & - \\
\hline 6 & Negative & - & - & - & - & - & - & - & - & - & - \\
\hline
\end{tabular}

EMB: eosin methylene blue; In: indole test; MR: methyl red test; VP: Voges-Proskauer test; Ci: citrate utilization test; K: alkaline; A: acid. *The screened bacteria was in accordance to Reference No. 15 . 
fermentation and observing the coliform characteristics. The morphological characteristic and the IMViC methods results were used to to differentiate $E$. coli and $K$. oxytoca. $(14,16)$ Meanwhile to differentiate Proteus sp., we need to further observed the TSIA results, to find the characteristics of gas and acids formation. $(15,16)$

This study found that the bacteria identified were Proteus sp., E. coli, and $K$. oxytoca, which are included

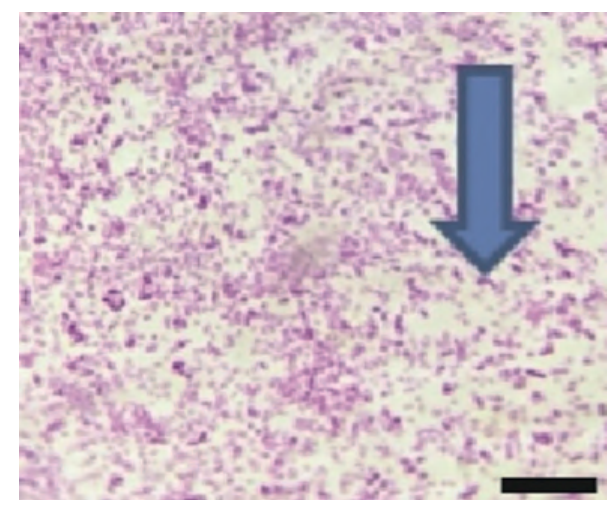

Figure 1. Proteus sp., as shown from the bacteria identified from sample no. 1. Black bar $=10 \mu \mathrm{m}$.

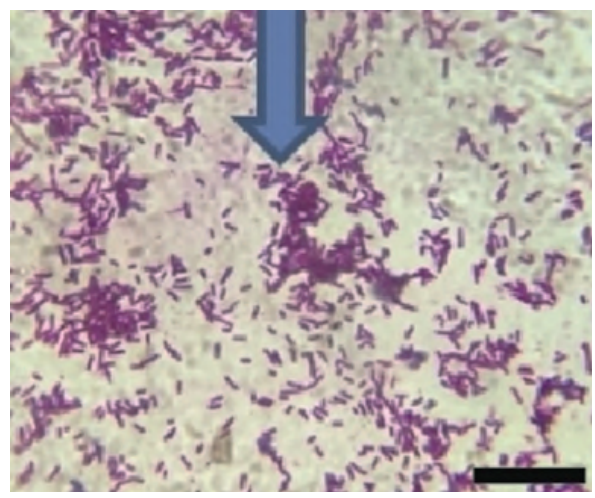

Figure 2. Escherichia coli, as shown from the bacteria identified from sample no. 3. Black bar $=10 \mu \mathrm{m}$.

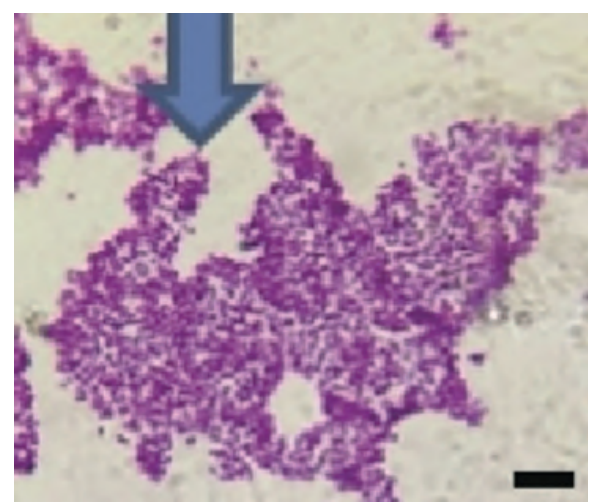

Figure 3. Klebsiella oxytoca, as shown from the bacteria identified from sample no. 4. Black bar $=20 \mu \mathrm{m}$. in the members of the Enterobacteriaceae family. The unhygienic environmental conditions are the main cause of bacterial contamination. Many drinking-water refill depots are not fulfilling the sanitation standard and located near the trash disposal site. During the process of water-refilling, the possibility of microbial contamination also exists, with the operator hygiene and sanitation of processing equipment as the contamination factors.

The result of our study was similar to a study in the Duri Kosambi area in Jakarta, which found a microbial contamination of $E$. coli originating from the unsanitary environmental condition, not from human/animal's faeces. Other microorganisms were also found, such as $K$. oxytoca, Proteus mirabilis and Pseudomonas aeruginosa, which are also pathogenic in humans.(6) Bacteriological tests conducted on drinking-water samples from refill depots in Jagakarsa, Jakarta, showed that the refilled drinking-water contained Staphylococcus aureus, however, no samples contained E. coli, Salmonella, Clostridium perfringens and $P$. aeruginosa.(17) Another study conducted to assess the quality of drinking water in Dehradun, India, found that $E$. coli, P. aeroginosa, Klebsiella sp., S. aureus and Proteus sp. was contaminating the drinking-water samples.(18) Meanwhile, a study in Maseru district, Lesotho, concluded that the main contributor of unhygienic conditions and practices that increase total coliform and $E$. coli percentages were unprotected water source that was contaminated from livestock faeces and laundry practices.(19)

The definition of clean water is different from drinking-water. Drinking-water has to be the clean water. However, clean water is not always safe to be consumed as drinking-water. The quality of drinking water must be kept safe for consumption. The drinking-water refill depots must be guaranteed for their cleanliness and sanitation. While working, the depot workers are also required to be clean, healthy, and use the recommended equipment to process of the water refilling.

\section{Conclusion}

Based on the characteristics observed from the microbiology and biochemistry testing, it was concluded that among six drinking-water refill depots in Abeli, three of them were contaminated by coliform bacteria. The identified bacteria were Proteus sp., E. coli, and K. oxytoca. Continuous supervision to the refilled drinking-water quality is needed to ensure the quality of drinking-water in Abeli and the other coastal areas of Kendari. 


\section{References}

1. Montgomery KS. Nutrition column an update on water needs during pregnancy and beyond. J Perinat Educ. 2002; 11: 40-2.

2. Cunningham FG, Leveno KJ, Bloom SL, Dashe JS, Hoffman BL, Casey BM, et al. Williams Obstetrics. 24th edition. New York: McGraw-Hill; 2013.

3. World Health Organization. Guideline for Drinking-water Quality. 4th edition. Geneva: World Health organization; 2011.

4. World Health Organization. Guideline for Drinking-Water Quality: Incorporating 1st and 2nd addenda, Vol.1, Recommendations. 3rd edition. Geneva; World Health organization; 2008.

5. Kristiyanti M. Empowerment of coastal communities through ICZM approach (Integrated Coastal Zone Management). Proceedings of the National Conference Multi Discipline Science. 2016 Jul 28, Semarang. 2016; p.752-60.

6. Tjampakasari CR, Wahid MH. Water quality of Angke River: microbiological of view. Med J Indones. 2008; 17; 82-7.

7. Research and Development Center of the Republic of Indonesian Ministry of Health. Basic Health Research. Jakarta: Ministry of Health Republic of Indonesia; 2013.

8. BSN. Bottled Water, Indonesian National Standard, SNI 01-35532006. Jakarta: National Standards Agency (BSN); 2006.

9. Kemenkes RI. Regulation of the Minister of Health of the Republic of Indonesia No.492 / MENKES / Per / IV / 2010 concerning Drinking Water Quality Requirements. Jakarta: Ministry of Health Republic of Indonesia; 2010.

10. Dirjen PP-PL. Guidelines for Implementing Drinking Water Depot Hygiene Hygiene. Jakarta: Directorate General of PP \& PL Republic of Indonesia Ministry of Health (Dirjen PP-PL); 2010.
11. Saimin J, Ristanti T, Hartati. The quality of drinking water refills in the coastal areas of Kendari City. Proceedings of the National Conference on The Role of Health Workers in Resistance Prevention Programs Antimicrobial (PPRA). 2019 Feb 14, Kendari. 2019; p.18.

12. Puspitasari E. Analysis of the factors affecting the quality of the chemical and microbiological drinking water at the drinking water refill depot in Tulung Agung District. J Quality Pub Health. 2018; 1; 104-12.

13. Bartram J, Pedley S. Microbiological analysis. In: Bartram J, Balance R, editor. Water Quality Monitoring - A Practical Guide to the Design and Implementation of Freshwater Quality Studies and Monitoring Programmes. Geneva: UNEP/WHO; 1996. p.1-27.

14. Sridhar Rao [Internet]. IMViC Reactions [updated 2006 Jun; cited 2019 May 10]. Available from: https://www.microrao.com/ micronotes/imvic.pdf.

15. Microbeonline [Internet]. Triple Sugar Iron Agar (TSI): Principle, Procedure and Interpretation [updated 2013 Jul 16; cited 2019 May 10]. Available from: https://microbeonline.com/triple-sugar-ironagar-tsi-principle-procedure-and-interpretation/.

16. Garrity GM, Bell JA, Lilburn TG. Taxonomic outline of the prokaryotes. Bergey's Manual of Systematic Bacteriology. 2nd edition. New York: Springer; 2004.

17. Radji M, Oktavia H, Suryadi H. Bacteriological examination of refilled drinking water in some of the refilled drinking water depots in the area of Lenteng Agung and Srengseng Sawah, Jakarta Selatan. Majalah Ilmu Kefarmasian. 2008; 5: 101-9.

18. Rajendra S, Rubin D, Abhishek M. Microbiological quality of potable water in Dehradun City. IRJP. 2012; 6: 130-7.

19. Microbeonline [Internet]. Triple Sugar Iron Agar (TSI): Principle, Procedure and Interpretation [updated 2013 Jul 16; cited 2019 May 10]. Available from: https://microbeonline.com/triple-sugar-ironagar-tsi-principle-procedure-and-interpretation/. 